\title{
9. Aboriginal Workers, Aboriginal Poverty
}

\author{
Ros Kidd
}

If I were a young Aboriginal woman living in Queensland between the 1920s and the late 1960s, there would be a one in two chance that my life was totally controlled by the Government. I would have no rights about where I lived, where and when I worked, my own future or the futures of my children. I would probably be removed to a government settlement where I would be separated from my mother and siblings from the age of five and confined in a dormitory, taught only basic English and arithmetic, and trained as a domestic servant. At thirteen or fourteen, I would be given some clothes and sent to a town or a remote cattle station to start my life of work. Many young boys were also sent to work on the stations, along with men and women trapped in a 51-week labour cycle.

\section{The 'Protection' Regime in Queensland}

The Queensland Government established this system of enforced labour in 1897 under The Aboriginals Protection and Restriction of the Sale of Opium Act. Under this law, and subsequent legislation until 1971, the Government granted itself powers to control the lives of anyone of Aboriginal descent, in order to protect them from physical, sexual and employment abuses. It set up a network of protectors - in most cases, the lead police officer in each district-whose surveillance during most of the twentieth century generated detailed files on all aspects of people's private lives. Critical police reports triggered government approval to deport individuals and families to distant missions or governmentrun settlements - often a life sentence. Aboriginal people were not told of the reason for such 'removals'; there was no due process and no right of appeal (Copland 2005). I have elsewhere detailed the abundant primary evidence of the appalling conditions endured by families confined on the grossly under-funded missions and settlements (Kidd 1997, 2002). This chapter will reveal whose interests were best served during the Government's long-running contract employment scheme.

It is a common misconception that settlements in Queensland were closed institutions, tightly excluding Aboriginal people from the wider community. In truth, the Government had no intention of supporting thousands of people on 
the reserves; ${ }^{1}$ nor could it afford - economically or electorally - to exclude such a vast, cheap, malleable workforce from the State's development. The 1897 Act introduced the euphemism 'work agreements' that no Aboriginal man, woman or child could refuse without punishment (Aboriginal child labour was still prevalent in the late 1950s). ${ }^{2}$

Contrary to the longstanding 'whitewashing' of Aboriginal labour from our economic history, these workers have been absolutely crucial to our development as a nation. By the mid-1880s, more than 1000 Aborigines were already in permanent work in Queensland, mostly in rural areas where white labour was scarce. A government survey in 1899 listed more than 2000 permanent workers south of the Tropic of Capricorn. By 1907, there were more than 3000 contracted Aboriginal workers across the State, nudging 4000 in the pastoral industry alone by 1920 , rising to 4500 in the early 1930 s and 5000 in the mid-1960s. ${ }^{3}$

Queensland was not alone in its 'protection' interventions and employment controls. Each State government, and the Commonwealth Government in the Northern Territory from 1911 to 1928, carefully crafted laws controlling Aboriginal lives and labour, and surveillance systems to force individuals to abide by them (Kidd 2007). If you were a person of Aboriginal descent, these governments could dictate where and when you worked, the type and conditions of that work, what you may be paid and if you could spend it. In Queensland, until 1968 in rural areas and until 1979 on government settlements, Aboriginal legislation overrode the raft of industrial protections enjoyed by every other Australian worker.

\section{Labour Conditions}

Official files amassed by the Queensland Government reveal how it executed its self-appointed mandate to 'protect' the employment interests of the Aboriginal people it controlled. The files show that for 20 years there were no limits on how many hours were worked, how hard was the labour, how bad was the treatment or the provision of food and living quarters. Minimum conditions were gazetted in 1919 (Queensland Government Gazette, 6 June 1919), but in the absence of any inspections widespread abuses continued. In 1921 the Chief Protector admitted shelter for many Aboriginal workers was 'worse than they would provide for their pet horse, motor-car or prize cattle'; in 1936 a group of families on one station had to live in the open with no protection from rain or wind; in the 1940s it was reported that most employers in the Gulf area thought

\footnotetext{
Queensland Parliamentary Debates, 1901, p. 1139.

Queensland State Archives [hereinafter QSA], TR1227:258 23.1.57.

COL/A140 99/3618, QSA; employment numbers from departmental annual reports.
} 
'anything is good enough for a nigger'; in 1959 one group of workers lived in an open shed without any bedding, light or table, and was paid only tobacco and matches each week. All these things the Government knew, because they are on files received and indexed at head office. Only in 1956, after the system had run for 60 years, did the Government instruct industrial inspectors to include Aboriginal employees in their tours of rural areas. Even then, as the records show, abuses continued: sexual assaults, wet living quarters, rough handling, beatings with chains, lack of water and cooking facilities, and widespread hookworm and ill health, especially among children. Clearly, the Government betrayed its mandate to protect Aboriginal wards from physical and labour exploitation.

\section{Wage Rates}

Acting as employment broker through its agents, the police protectors, the Government also had a duty to negotiate wages commensurate with the skill levels and market demand for Aboriginal workers, who were chiefly sent to outlying areas where white labour was scarce. The Government charted the value of this contracted workforce through regular surveys of local protectors. In the first years of the past century, the Government knew Aboriginal workers were often regarded as more reliable than and superior stockriders and bushmen to their white counterparts, yet it set their wage at about 3 per cent of the white rate. In the early 1930s when white rural labour was described as 'often useless' and Aboriginal labour as 'indispensable', 4500 Aboriginal workers were sold at about 40 per cent of the pastoral award rate. ${ }^{4}$ In 1949 Aboriginal wages were as low as 31 per cent of the award rate, and only 59 per cent in 1956, when an employment inspection confirmed the pastoral industry was entirely dependent on Aboriginal workers, particularly in remote areas where white stockmen were rare. The inspector said the entrenched mentality was to pay 'as little as possible for Aboriginal workers', while 'white men of markedly less ability and industry receive higher wages and better living conditions than Aboriginals who are better workmen'. ${ }^{5}$ By the mid-1960s, the 5000 Aboriginal workers were paid only 70 per cent of the award rate. The Queensland Government defied the 1966 'equal pay' judgment of the Commonwealth Conciliation and Arbitration Commission directing Aboriginal pastoral workers be paid the same rates as their white counterparts, by simply categorising its controlled Aboriginal workforce as 'trainees', and continuing to sell them at a discount, although most had decades of skill and experience. ${ }^{6}$ Only after 1972 were Aboriginal pastoral

\footnotetext{
Comparing rates under successive Aboriginal regulations with the contemporary pastoral award.

Box 16 22, October 1956, SRS 505-1, QSA.

28 May 1965, SRS 505-1 1A/29, QSA.
} 
workers free from conscripted employment. For the first time, elderly family members and wives who had been compelled to work for free on the stations could refuse such exploitation.

The Government's own records thus confirm that the prime motivator for the Aboriginal labour market was the needs of rural industries: the supply of as many men and women as required for a price that the market claimed it could bear. Send them out to the remote areas that white workers shunned, arrest them and return them if they abscond; do not look too closely at hours and conditions. But that was only half the story. The other half was the rank financial exploitation of this captive workforce. There is no doubt that generations of Aboriginal people were mired in poverty despite decades of contracted work. The files reveal that while they were trapped in poverty, the Government grew fat on their earnings.

\section{Savings and Trust Funds}

For the whole of its 70-year contracted labour system, the Government gave employers the right to pay into workers' hands between 30 and 80 per cent of their wage. But the Government never bothered to secure this payment despite warnings from both protectors and auditors that workers were routinely cheated of this 'pocket money'. An internal inquiry in $1932^{7}$ concluded it could be 'reasonably assumed' that workers did not get this money. In a 1943 survey of pocket money payments, protectors said the whole system was a farce and a direct profit to employers; in 1956 protectors described the system as useless, futile and out of control, with workers 'entirely at the mercy' of employers who simply doctored the books. In the mid-1960s, auditors again condemned the Government's continued lack of control of pocket money payments. ${ }^{8}$ Records show that in the 60 years to 1968, successive governments knew the Aboriginal workers it controlled were being cheated of potentially 50 per cent of their wage. They knew these systemically impoverished workers were effectively subsidising the State's pastoral interests.

What of the portion paid directly to police protectors, ostensibly to 'protect' Aboriginal earnings from European cunning and Aboriginal incapacity? The Government knew from the start that its agents, the police protectors, were often incompetent and fraudsters, yet it continued this system. As early as 1904, and again in the 1920s, it introduced a thumb-print system to reduce rampant fraud. It did not work. A public service inquiry in 1922 revealed absolutely no

7 Report on the Inspection of the Office of the Chief Protector of Aboriginals, 9 November 1932, A/58856, QSA.

8 Audit Report 1964-65, TR254 1B/69, QSA. 
supervision of the 8000 rural savings accounts, and said police practices were so unreliable workers should be allowed to appeal dealings on their accounts. ${ }^{9}$ The 1932 inquiry found that 'the opportunity for fraud existed to a greater degree than with any other Governmental accounts'. The Chief Protector again admitted there were no real controls over official dealings on private accounts, and again refused to allow workers to check dealings on their accounts.

When the Government did centralise the bulk of the rural savings accounts in Brisbane in 1933, in order, it said, to minimise police fraud, ${ }^{10}$ it promptly locked about 80 per cent of these savings - more than $\$ 12$ million today ${ }^{11}$ - in investments, and kept the interest bonus for itself. Until the late 1960s, only about 20 per cent of their savings were available at any one time for Aboriginal workers. The files are full of rejections for those who asked for a few dollars of their own money.

In 1904 a trust fund was set up to hold monies owing to, or saved by, missing or deceased workers for distribution to their families; a second trust fund was set up in 1919 by simply taxing all Aboriginal savings for an unemployment relief fund. Internal investigations show both trust funds were consistently raided for government costs. In the decade from 1925, covering the Depression years, the Government simply transferred to itself more than $\$ 930000$ (in today's money) from Aboriginal savings accounts and more than \$3.5 million from the two trust funds ${ }^{12}$ - money that has never been repaid. Vast sums from the Commonwealth child endowment paid to Aboriginal mothers after 1941 were also transferred into state revenue, by paying only a fraction to settlement mothers and by reducing grants to the missions by the amount of incoming endowment. From 1960, invalid, aged and widows' pensions were 'diverted to revenue', ${ }^{13}$ bringing an annual bonanza of more than $\$ 500000$ (in today's money) in 1960, rising to almost $\$ 750000$ by 1964 . Meanwhile, the people whose lives were supposed to be improved by the pensions struggled and died in poverty. When Aboriginal people in Queensland finally got control of their lives and their finances in the early 1970s, many found to their horror that their new bankbooks showed pitiful balances despite decades of work and financial privation. Those who queried head office were told that the records were too inconclusive and so many files lost or destroyed that it is impossible to confirm claims of missing money.

9 Report on the Office of the Chief Protector of Aboriginals, 15 March 1923, A/69452, QSA.

1014 November 1933, TR1227:129, QSA.

11 All amounts converted to approximate equivalent today using the retail price index.

126 November 1935, A/58856, QSA.

1317 March 1959, SRS 505-1, Box 91, QSA. 


\section{Fighting for Justice}

As Aboriginal workers and their families become aware of the wealth of evidence of government financial mismanagement across generations, there is increased action for justice. Government responses have been characterised by denial, miserly compensation and non-disclosure of file evidence.

\section{Underpaid Wages}

At a 1996 Human Rights Commission hearing into the charge by seven Palm Islanders that the Queensland Government's entrenched underpayment of community wages was illegal after passage of the 1975 Racial Discrimination Act, the Government said I could be sued for damages if I presented evidence from its own files to the commission. This evidence convinced the commission to conclude that the Government had 'intentionally, deliberately and knowingly' underpaid six of the seven claimants, and it recommended compensation of $\$ 7000$ each. $^{14}$ The Borbidge Coalition Government initially dismissed the findings, paying the $\$ 7000$ only after action was launched in the Federal Court, and only after demanding claimants sign an indemnity against further legal action. Yet the Government knew those claimants were due amounts varying between $\$ 8500$ and $\$ 21000$.

When the Beattie Labor Government extended the $\$ 7000$ compensation in 1999 to all community employees illegally underpaid from $1975,{ }^{15}$ we now know it had already settled 22 actions out of court, one for $\$ 4000$ (about one-quarter of the debt showed on government records), and 21 for $\$ 7000$ (where official estimates of underpayment ranged between $\$ 13000$ and $\$ 27000$ ). The Government again demanded it be indemnified against future legal action, knowing that most claimants had never seen the official records detailing what they might really be owed. Fewer than half the potential claimants took the $\$ 7000$, costing the Government almost $\$ 40$ million-less than one-quarter of the profit it had made from the underpayment of community workers in the decade from 1975. Two workers who each sued the Government for $\$ 100000$ for their underpaid wages (The Courier-Mail, 28 November 2002) settled in 2004. In 2006 several hundred workers on two former Lutheran communities won their case on appeal, and were paid based on their wage records; many received more than $\$ 20000$; one was paid four times that much.

14 HREOC Decision No. H95/74-80, H96/88, 24 September 1996, Human Rights and Equal Opportunity Commission.

15 Queensland Parliamentary Debates, 26 May 1999. 


\section{Stolen Wages}

In May 2002, Premier Peter Beattie admitted there were 4000 potential litigants waiting to sue the Government for the stolen wages ${ }^{16}$ - that is, the wages, savings, child endowment, pensions and inheritances lost during 70 years of government mismanagement. He offered compensation of \$55.6 million, which he said was 'generous', despite admitting my own research indicated about $\$ 500$ million is in question. This offer was a maximum $\$ 4000$ per person; thousands of deceased account holders were simply disqualified; and again claimants had to sign away their legal rights. Facing a barrage of public condemnation and a poor uptake of only \$20 million, in August 2008, the Bligh Labor Government reopened the scheme and increased the maximum payouts to $\$ 7000$ (The CourierMail, 18 August 2008). In November 2010, it declared its intention to tip the $\$ 20$ million still unclaimed into the notoriously misused Aboriginal Welfare Fund for distribution as education scholarships, in blatant contempt of its own survey in which more than 90 per cent of respondents demanded the whole stolen wages allocation be distributed among eligible claimants as promised by the Premier in May 2002 (National Indigenous Times, 11 December 2008).

\section{A National Scandal}

Exploitation of Aboriginal labour, wages, savings and entitlements was not peculiar to Queensland. All State governments, and the Commonwealth Government in the Northern Territory, ran contract labour systems and banking controls. In 2004 I wanted to generate a national report with detailed submissions from local experts, but this gradually shrank to my compiling a summary gleaned from other research work, and was published by Australians for Native Title and Reconciliation (ANTaR) in 2007 as Hard Labour, Stolen Wages (available free online from their web site). ${ }^{17}$ In 2006 I met Democrats Senator Andrew Bartlett at a stolen wages strategy meeting and he suggested a senate inquiry should look into the issue nationally. After months of persistent lobbying by Bartlett, the inquiry was launched in 2007, attracting submissions from around Australia, which confirmed the terrible losses suffered by those whose lives and livelihoods were controlled by various governments. Initially, the Queensland Government scorned the inquiry, hastily appearing only on the last day. The evidence is damning; it is all on the Senate's web site. ${ }^{18}$

\footnotetext{
16 Queensland Parliamentary Debates, 16 May 2002.

17 <http://www.antar.org.au/sites/default/files/stolenwages.pdf>

18 <http://www.aph.gov.au/senate/committee/legcon_ctte/completed_inquiries/2004-07/stolen_wages/ submissions/sublist.htm>
} 
Predictably, all governments are in denial. I believe the WA Government has made a preliminary investigation of its records relating to the management of private Aboriginal monies, including endowment and pensions, but it has refused to disclose this information to the individuals and families concerned. The NSW Government has initiated a reparations scheme to repay money shown to be outstanding to particular individuals. This scheme takes no account of wages and entitlements lost through decades of mismanagement. The Victorian Government committed only a few days to its official investigation of its financial records. These governments - and those who to date have refused to address their role in this national scandal - are claiming that 'lost' records are a bulwark against legal accountability.

\section{International Precedent?}

Given there is overwhelming evidence of negligence and mismanagement by successive Queensland governments, I have long been convinced that it is the Government that should be in the dock and on the defence, not an individual trying to provide cast-iron evidence of fraud on his or her account-evidence that the Government might have withheld, lost or destroyed. I am inspired by the case of Elouise Cobell, ${ }^{19}$ an enterprising woman of the Blackfeet tribe of Montana, who brought action against the US Government in 1996 on behalf of thousands of individual Native American men and women who were cheated of royalties for oil, mineral and other leases during more than a century of government mismanagement of their accounts. Government claims that individual entitlements cannot be proven because so many records have been lost and destroyed over time were, as the judge pointed out, primary evidence of the breach of their fundamental trust duty to keep proper records.

In 1999 the US courts found in favour of the Cobell claim, which comprises half a million living and deceased claimants; one government estimate suggested US $\$ 40$ billion was at stake. The Bush Administration refused to accede to court demands to negotiate a settlement. In December 2009, the Obama Administration provided US $\$ 3.4$ billion to finalise this massive class action.

There is a major hurdle for such a case in Australia. In the United States, the courts had already declared that, in its stewardship of the enterprises on Indian reserves (as they were referred to) and management of individual bank accounts, the Federal Government was a legal trustee of those Indian interests with full legal obligations. In Australia, as the many supportive lawyers in our battle informed me, our courts see things differently. In their view, the people are

19 The detailed history of this case can be found on $<$ http://www.narf.org $>$ and $<$ http://www.indiantrust.org $>$ 
the ones who empowered the governments to implement their wide-ranging 'protection' schemes, and it is not the role of the courts to interfere with how governments carried out this mandate. The lawyers suggest our courts might not find our governments are legal trustees of Aboriginal interests. Cases mounted for members of the Stolen Generations bear this out.

But I firmly believe that a stolen wages case, based on the wealth of incriminating financial evidence on government files, will prove different. It is much harder to argue 'benign intent' in illegally using private savings than in removing children from their families. To convince the legal profession and the courts, I wrote Trustees on Trial (Kidd 2006), analysing national and international cases relating to trust law and fiduciary duties, and applying those legal prohibitions and responsibilities to the negligent and exploitative conduct of successive Queensland administrations. Let me mention a few of the legal duties of a trustee: a trustee must protect the trust property, must keep proper records of accounts and provide full information to any beneficiary requesting it, and must not profit from, or have personal interests that conflict with, the trust. You can see the connections. For any trustee, loss of records is not a defence; it is a fundamental breach of trust duties.

In September 2009, the Queensland Council of Unions launched court action for breach of trust on behalf of Conrad Yeatman, whose labour and wages were controlled by government mandate from the age of fourteen. In December the Government lodged its defence. It claims it has no responsibility for the missing wages and savings of the Aboriginal and Islander people it controlled for most of the twentieth century. The Government states that it all happened too long ago and records have been destroyed. ${ }^{20}$

In my view, the Government's blatant denial of the evidence on public record shows contempt for fundamental human rights. Throughout the twentieth century, governments lied to the Australian public about their flawed guardianship of thousands of Aboriginal families; this was no benign paternalism. Governments mishandled the money of the poorest people in Australia who were forced to be utterly dependent on their integrity. Government stonewalling continues this rank injustice; their contemptuous disregard for historical accountability continues the whitewashing from our national history of the mammoth part played by Aboriginal workers, and feeds the pernicious insinuation that Aboriginal poverty today is an outcome of a cultural aversion to work. How different would their lives have been - and those of their descendants today - if these highly valued essential workers had not been cheated of their wages. Why should they not be compensated for this institutionalised loss? 
Indigenous Participation in Australian Economies II

If I were an Aboriginal woman who had been trapped in this system, I would be hoping that my day in court would not only bring me justice and reparations but also inscribe on the public mind the vital labour input of Aboriginal people in the generation of our national wealth, and constant participation in the national economy.

\section{Postscript}

In March 2012 the WA government offered an ex gratia payment of $\$ 2000$ to surviving residents of government settlements born before 1958 who can provide evidence of withheld entitlements, estimating that fewer than 1500 people may be eligible.

\section{References}

Copland, M. 2005. Calculating lives: the numbers and narratives of forced removals in Queensland 1859-1972. PhD thesis, Griffith University, Gold Coast, Qld.

Kidd, R. 1997. The Way We Civilise. St Lucia: University of Queensland Press.

Kidd, R. 2002. Black Lives, Government Lies. Sydney: UNSW Press.

Kidd, R. 2006. Trustees on Trial. Recovering the stolen wages. Canberra: Aboriginal Studies Press. 